\title{
Notes on changes in the highland district of Appin of Tayside
}

\section{John Stewart Junior}

To cite this article: John Stewart Junior (1911) Notes on changes in the highland district of Appin of Tayside, Scottish Geographical Magazine, 27:7, 359-368, DOI: 10.1080/14702541108555084

To link to this article: http://dx.doi.org/10.1080/14702541108555084

册 Published online: 30 Jan 2008.

Submit your article to this journal $₫$

Џll Article views: 5

Q View related articles $๘$ 
times miles in width, cut by a great number of rivers, which drain it and bring its abundant waters to the sea. The trend of the hills and mountains is principally east-west, which causes great trouble to explorers, as the ridges cannot be followed, but always have to be crossed. During the expeditions of 1907 and 1909 eruptive rocks were not found. The mountains we crossed proved to be of recent formation. The Wilhelmina peak consists of alveoline limestone. Eruptive rocks have been found near Geelvink Bay. The Wichmann Mountains consist partially of sandstone. Concerning the snow, I may mention that we did not meet with real glaciers-the heat of the tropical sun must prevent their formation -but we found many traces (the above-mentioned lake and scratches on the rocks) that they have existed. We saw on the top of the Wilhelmina peak the so-called firn.

Ethnology.-A distinction must be made between the Papuans living in the plains near the river and those in the mountains. The river Papuans live chiefly on sago and bananas, and have as animal food hogs, fish, kangaroos, cassowaries, etc. As sago does not grow in the mountains, these Papuans eat principally yams and bananas, and also hogs, rats, and mice. Both of these tribes live in a typical Stone Age. Their arms are bow and arrows, spear, club, and stone axe. Their arrows are not poisoned. None of them wear any clothing; not even the people who live above 10,000 feet. It is remarkable that they do not know the use of bark. I am not convinced that they are cannibals. I collected about eighty human skulls, and on asking a native where the remaining portions of the skeletons were, he gave me to understand that they were eaten. It is possible that he misunderstood me; still those skulls are valuable from an anthropological point of view, as we can be sure that they belong to a race which is free from mixture with other races. Besides their weapons, they never. go out without their bag, containing tools for daily use. They give evidence of great skill in making their canoes with stone axes. I happened to be in their village when they were busy with their work, and they soon understood the superiority of iron tools.

\section{NOTES ON CHANGES IN THE HIGHLAND DISTRICT OF APPIN ON TAYSIDE.}

By John Stewart, Junior, Tegarmuchd, by Aberfeldy.

(Continued from page 291.)

\section{Industrial aNd Agricultural Changes.}

These have affected the whole population-those engaged in agricultural and non-agricultural work. I begin with the latter class.

The parish of Dull is divided into two parts, the parish landward (of which this is the home division), and the parish burgh (Aberfeldy), with Weem parish between. The burgh and the rural districts 
have completely altered their mutual relations in the course of the generations. In the beginning of the eighteenth century Aberfeldy was merely a hamlet of a few black houses, while Dull and Weem were centres of some consequence, as understood at the time. Wade's Bridge gave Aberfeldy a fillip in the eighteenth century, and in the nineteenth the railway made it a small town. As far back as I can remember, these places have been in the Aberfeldy district; in my grandfather's and even my father's time, Aberfeldy was in the district of Weem. At Weem the Courts were held. It was the polling centre of several parishes, and so on. Everything except farm-work is centralised in the burgh. It has our banks, our shops, our auction mart; and-barring a few estate workmen-our joiners, masons, plumbers, slaters ; our tailors, shoemakers, weavers, etc.

Now, in referring to the decrease of the rural population, many writers are apt to think it has come about owing to the smaller number of people on the farms. That is only part of the truth. While the agricultural workers are fewer, the other class of workers has gone from the parish landward entirely. The burgh has increased; the landward part has decreased.

In addition to the villages of Dull and Camserney, a row of cottages stood beside every farmstead. My father remembers when there were three schools instead of one in Appin; four smithies instead of one; at Camserney, where only the sawmill remains, there were a meal-mill, a wool-mill, a lint-mill, and a whisky-mill. He knew quite a large number of hand-loom weavers, tailors, shoemakers, joiners, cartwrights, drystone dyke-builders, masons, and general labourers. Those people, most of them, besides working at their trades, did a little at the farms on special occasions, such as hay and harvest time. Indeed many of them had their cottages from the farmers and paid the rent in work.

Those were the times before the shootings became valuable. One gamekeeper looked after the whole valley, a little creature whom many a man could carry to the top of Dull Rock on his back. A number half-lived on poaching of every kind. The old Gaelic saying ran-"It's no great sin to cleek a salmon in a pool, or snare a hare in a thicket." It was after the day of cattle-lifting, however, and it could not be true in the sense meant by Bailie Nicol Jarvie, that the one half lived on the land and the other half on plunder.

Those were also the times when the Chancellor of the Exchequer did not require so many millions, when the Government was not allseeing, and the revenue officers not always invincible and incorruptible ; when the parish was continually searched for hidden treasure, and nothing gave the country-folk more delight than listening to tales of gaugers belaboured or outwitted by smugglers. A Weem man fought in the "Battle of Corriemukloch," along Crieff way, where a party of Scots Greys, sent to apprehend a strong band of smugglers, stuck with their horses in the boggy ground, and had to return without accomplishing their purpose. My father's uncle-one of the then tenants at Tegarmuchd-was fined $£ 50$ (though not a smuggler himself) for aiding, along with several other men from here, a gang of smugglers in their 
attempt to get their barrels into Perth by force, the most foolhardy feat ever attempted. One of his cousins suffered a year's imprisonment for smuggling. The last of the smugglers of the place is survived by a son living at Camserney.

Those were the times when crowds of folk went as harvesters to the south. Apprentices had a month's harvest in their bargain. They trooped off to the Carse of Gowrie, to Fife, even so far as the Lothians. The harvest in the south being early, they had that finished before starting the harvest here. Among those who used to go were Thomas Menzies, afterwards one of the national heavy-weight athletes, Lachie M'Intosh, a noted long-distance runner, my maternal grandfather from the sawmill, and a tailor, the only man of my time who told an old fairy story as true. In the year of short corn, '26, it was on the Dull Summer Communion Day, the second Sunday of July, that word came from the south to start-an early harvest indeed. The accommodation of the harvesters in barns and the like was only so-so, and it was a serious business for them in wet weather, as they generally got payment by results, and there could be no results while Jupiter Pluvius reigned. When hired for a month, the pay was a shilling a day-a fourth and no more of what has often been given even here. I am not aware that any serious charges were alleged against them. They were said to be famous orchard plunderers, some of them, but that is not to be wondered at in the case of people who never saw an apple when at home.

A word may be said of two industries carried on for a long while in the country. The one was the cultivation and manufacture of flax, or as it was called "lint." For the encouragement of this industry in the Highlands several lint-mills were put up throughout the country by the Government. The mill of this district stood at Camserney. Near the village, lint-ponds were constructed for steeping the lint-at ane place in a bit of marshy ground, at another where water was diverted from the burn. My father knew all the many processes, from the sowing of the lint seed to the wearing of the lint shirt. The industry died off altogether fifty to sixty years ago. The other industry was whisky distilling. I do not mean the illicit still-in Gaelic, "the black pot," but the legal manufacture of the "water of life." The laird erected three stills in the strath, at Camserney, Tegarmuchd (Wester), and Coshieville. My grandfather, with several other farmers, had a share in the Camserney still. It perished about the same time as the flax business.

The little mercantile business the people had was with Perth, before shops sprang up in Aberfeldy, and every district had its Perth carrier, who also carried the business letters because of the excessive postage.

Neither my father nor my grandfather saw a quern going, and neither, perhaps curiously enough, saw or knew anything about quernstones, so early did mills flourish by the burn.

While with a few exceptions mechanics and labourers other than farm workers have abandoned the parish landward, and are to be found only in the burgh, the agricultural section of the community, in greatly decreased numbers, has remained in circumstances greatly changed from what they were in the days of the forefathers. 
As far back as my father remembers, the extent of tilled land has been practically as it is now; so, too, the division of the valley into holdings separate and distinct from each other, although, as mentioned already, the holdings were smaller, and consequently the tenants more numerous. Broadly speaking it was towards the close of the eighteenth century that the modern or present agricultural order originated.

In my grandfather's early life, there was no rotation, as we understand the term. The only crops were oats, barley, potatoes, and a patch of flax. Corn succeeded corn sometimes for three years; which would now be called mis-cropping. Subsequently grass seeds, rye-grass and clover, were introduced: hence rotation hay, as distinguished from meadow or permanent hay. The whole of the grazings on hill and braes were held in common; all the cattle, horses, and sheep of all the tenants grazed together. The arable land was in run-rig. A tenant had not his holding all in the same place and marked off by boundaries from neighbouring holdings as now. There was an endless succession of small bits or patches. A man never had his different plots beside each other: just a rig here and a rig there alternately, and never the same rigs for more than one year running. Every year he had a shift of ground, and that kept them all mixed up. Enclosures were unknown, and all had to unite in guarding the tillage, whether against wild beast or against wild man.

Again, there were no wheeled carts, only sledges or "carns." The carn-roads on which the peats were sledged down the hill may yet be noticed in certain parts of the braes. They are simply deep narrow tracks. Sometimes these are to be met with parallel to and close beside each other. When one became too deep it was changed.

The lairds erected corn-mills, and the tenants were "thirled" to a particular mill, that is, by agreement they had to send their corn to be ground there.

In those days, the money rent was probably not a third of what it afterwards became. Indeed, the rent was mostly paid in kind, or "kain" as it was called in the old farm leases, and in servitude-in cattle, poultry, peats, kain carriage, and work on the home farm. Even in my father's tenancy, long after the rents were raised, "kain carriage" continued to be in force. Before the coming of the Highland Railway, he was among those that had to do "kain" to Perth, going for coals and other things required at Castle Menzies, and to Craiglea Quarry for slates. The tenants had also to cart the oak-bark to the tanneries at Crieff, Perth, and Kinross. A few head of poultry continued to be given in : that was an insignificant item latterly. So many cart-loads of peats formed another item : the laird's peats, in Gaelic, the Lord's peats. The Gael was then very loyal to his chief. Yes, but all the same, he learned long before the discontinuance of peat-casting, to give the brown or yellow, the inferior light kind, and to keep the black and hard peats for himself. On one occasion the laird, accompanied by another gentleman, was passing over the hill. Coming to a stack of brown peats, he said to his companion, "These are the peats they will send me. They're easily known." 
My father has certainly witnessed changes in all directions. A systematic succession of shifts or rotation has been established. Oats, green crop, i.e. potatoes and turnips, barley, hay-the four-shift or original form of regular rotation. To hay, well within his recollection, succeeded a fifth, pasture, partly owing to the deterioration of the rough or permanent pasture on the braes, partly by reason of the falling value of grain, and the high prices ruling for cattle. In his time the flax business has gone, rye, too, has been given up, and now barley has almost disappeared. Far more land used to be under potatoes. Owing to cattle-feeding the green-crop is now almost all turnips, and yet he remembers when turnips were first sown in the district. A very small piece of ground was set apart for them; they were so rare and precious then that the younger folk used to go to the fields to steal a turnip just as they would go to an orchard to steal apples.

A lime-kiln was then possessed by nearly every tenant, and lime universally applied to the land. The quarry was up on the hill about three miles above Coshieville. In his time artificial manures have come in. Stone dykes acted as boundaries and fences above the road, but he remembers when there was not a fence of any kind on the haugh between Wade's Bridge and the Point of Lyon. Before the introduction of wire-fencing, every holding, great and small, had its herd. There he stood, stick in hand, and nothing on his feet, keeping the cows out of the corn. It was supposed that he did not put them out of it, i.e. did not let them in. It was an easy, a healthy, and a wearisome job. When wire-fencing became partially the fashion, and he had only a side or two to watch, the work was not nearly so constant and he was not always at his post. Sometimes he slept, naturally enough, being out from early in the morning till late in the evening; sometimes he "guddled" in the burn, or ditch. Of this the cows would be sure soon to take advantage, and he would then be in a hurry. In the race the kye generally had the best of it. At stone-throwing he was an adept. In almost every byre, or on almost every pasture, a cow might be seen minus a hom. An irate farmer once asked his son, who herded, how one of the cows got a horn knocked off. The boy, not quite so truthful as young Washington, replied: "There was a strong gust of wind just now, and if that did not do it, I don't know how it happened." For the season of five months or so before the crops were secure, the hired herdboy received in wages $£ 1$, afterwards raised to $£ 1,10$ s., and his food.

Among farm animals, the black-faced sheep have kept their place on the moor from time immemorial. The old Highland cattle are gone, having been supplanted by the short-horn and Ayrshire breeds, in turn partly ousted now in these districts by the black-polled, the hornless "black doddies." The old Highland breed of horses, the small light Highland garrons, are gone from these arable farms at least, and their place taken by heavier Clydesdales, not pure, however. As far as my observation goes, grey is the most persistent colour in horses. $\mathrm{My}$ father remembers when hardly a grey or white horse was to be seen in this vale. They are quite numerous to-day. Our grey mares have almost always grey foals, whatever the sires, but very seldom is there a 
grey sire. That is intentional. The colour is unpopular with farmers ; white horses are more difficult to groom, the least dust showing on them. As ever since we came here, all the horses, the two pair, have been grey or white, Tegarmuchd has been occasionally known as "White Horse Farm." My father was the first tenant-farmer in the district to get a set of leather harness. He has seen the clumsy iron graips and forks, etc., made in local smithies, replaced by superior steel articles. $\mathrm{He}$ has seen the horse-rake take the place of the hand-rake for collecting the rows of hay, the coming of iron-harrows, chain-harrows, grubbers, cultivators, drill-harrow, double mould plough, etc.

Very remarkable have been the changes in connection with threshing and harvesting. When he began his tenancy he had no threshing-mill. He threshed with the flail. I never saw one. Their use being over, they soon vanished, as they were simply two long sticks tied together by a leathern thong. The old barns were specially constructed with a view to the kind of threshing in vogue. In this strath, practically all the houses, farm-houses, as well as steadings, were placed east and west, with the front facing the south. But on every holding stood one house by itself, north and south, with a door on each side exactly opposite. The reason was that in this country the winds are generally across country, east and west, and when the corn and the chaff together lay on the barn floor and had to be separated, the two doors were opened, and if the wind was blowing, whether east or west, entering one door it would drive the chaff out by the other: "the chaff which wind drives to and fro." The flail was hard work, and took a large amount of time. On big farms flailers were employed for the purpose.

In harvesting, the methods have altered more wonderfully still. My father remembers when all the corn was cut with the sickle. "Oft did the harvest to their sickle yield." Then they took the scythe for it. Then the reaping-machine astonished the rusties with its whirring and rapidity; and, within the last few years, to erown all, steps in the binder. From sickle to binder : it tells its own tale.

While mechanical inventions and appliances have benefited the farmer immensely in one way, enabling him to carry on his business with fewer hands at a time when hands were beginning to become scarce, in another way they have injured him. Coach-horses, of which so many were required when big hotels sprang up on the opening of the Highlands in the last century, have been driven off the road by the motor car. That means far less demand for hay and corn.

Buying and selling, too, are now conducted somewhat differently. The establishment of the auction mart in the country has had a good deal to do with that. Prior to its obtaining a footing, all the cattle, etc., were bought by travelling drovers, or were sold at the great fairs and trysts which were then numerous. Those fairs, "feile," were generally held half-yearly, the greatest towards the end of the season when the stock came off the grass. The most famous fairs near us were those at Kenmore, held monthly, and the yearly three-day fair- "FeileKate" (Kate's Fair), held, the first two days at Fortingall, and the third day at Coshieville. Big crowds of people-for the country districts 
that is-gathered at them. Country-folk then were more easily gulled. Sharpers and cheap-Johns did a roaring trade.

A decided change for the better remains to be recorded in another direction. The standard of living is higher, farm-servants are more humanely treated, and no farms known to us have the bad name for unsavoury meat that obtained in other days, especially on upland holdings, where "braxy" mutton was common.

\author{
Changes in Customs and Beliefs. \\ "The Highlander, whose red claymore \\ The battle turned on Maida's shore, \\ Will on a Friday morn look pale, \\ If asked to tell a Fairy Tale."-Scott.
}

Perhaps the most striking feature in modern Highland social life has been the passing away of the "ceilidh" (pronounced somewhat like " kaily")-a call or visit. In its palmy days it was not merely individual visitation: in the long winter evenings people went in bands from one house to another, generally a night in one house, another night in another, and so on, the women taking their spinning wheels with them. All the talk presumably was story-telling, stories of supernatural beings and manifestations, fairies, witches, ghosts, apparitions, second sight and the like. It is remarkable how little passing events engaged the attention, neither was much interest taken in the traditional tales of their national history, the conflict of clan with clan, and in latter days the collision of the tartan and the scarlet, as at Killiecrankie and Culloden.

Young children, listening to these weird stories, got their minds so full of "bogies" that fright prevented their venturing out alone in the dark. Marny adults were not much better. No man when alone by night would say, "M`Raw, give me my horse"-for fear he should be carried off on horseback to Fairyland.

The tailor already referred to, who died fifteen years ago, aged eighty-five, used to say that many of the fairy-tales were not true. One, however, he could give as absolute fact. It was what was well known at the time to have happened. A smith at Coshieville while out on the public road one night was suddenly lifted off his feet, and carried to the Bridge of Balgie in Glenlyon by an invisible party of fairies.

In this part of the country the belief in fairies and witches died long ago. Other beliefs lingered on, such as the Evil Eye, and peculiar notions as to diseases of cattle. Perhaps the "second sight" and the belief in apparitions or spirits have been the most persistent and have survived longest. Even in my own recollection a woman lived near Tummel Bridge who was credited by many with the gift of seeing things that happened elsewhere. The friends of two men who were drowned within a few years of each other in the Tay went to her, inquiring in what place the bodies were to be found. She was successful in the 
first case and it caused a great sensation: the second was a failure, her upholders merely saying she could not be expected to see everything.

Another old belief may be mentioned. It was firmly held that "water-bulls" existed in Loch Tay. They were said to have come occasionally to where the cows were grazing on the Loch-side. The calves resulting therefrom were easily known from the shape of their horns.

An old Comrie Ferry story, formerly often told, may now be referred to. Sometime in the eighteenth century, a virulent epidemic or pestilence raged in the country. It was called in Gaelic "the great disease." The site of houses above Milton, which were burnt after it, may yet be pointed out. One of the monthly fairs was being held at Kenmore, and as no bridge spanned the Lyon at Comrie, people had to go either by ford or by ferry. A stranger asked to be ferried over. The ferry-man, thinking there was something mysterious and uncanny about him, and thinking, perhaps, he might not be a man at all but an apparition, was very polite and obliging, and said :- "When I meet a thorough gentleman like you, my conscience prevents me from taking the fare." When they parted, the strange visitant remarked, "I am 'the great disease'; to-day I will hang as a black cloud over Kenmore, but don't you be afraid, I will not harm you a bit, as you did not charge a halfpenny for ferrying me across the Lyon." If a spirit, it must have been an uncommonly poor one that couldn't get to the other side without the help of a ferry-boat; if a man, it was too bad of him to personate the pestilence for the sake of doing a poor Highlandman out of a halfpenny.

The belief in sacred stones may be alluded to owing to a sensational case here in the first quarter of last century. Different stones, historic and prehistoric alike, were considered sacred, and it was maintained they could not be removed with impunity. At the period referred to, three crosses stood at Dull, and the then factor, a Mr. Campbell, had two of them taken away. After acting as gate-posts at Camserney Cottage (estate office), they were afterwards transferred to the old kirk at Weem. The horse-belonging to a man of Dull-that removed the stones, became ill that very night, and died. Shortly after, the factor intended riding on horseback to Rannoch. While going up past Coshieville, he lost control over the horse-a bad one-which galloped down, and went right over the old bridge into Keltney Burn Den. Both rider and horse perished. This eaused great talk throughout the country. The stones were blamed for it, or rather, the removal of these crosses was popularly believed to be the cause of the double catastrophe.

What with the smugglers and the fairs, the "ceilidhs," the "guisers," and the Old Days: the big weddings, the big funerals and the big communions: the crowded peat-mosses and the crowded harvest fields: the odd "characters," the two or three harmless insane persons, and two or three dozen other persons just slightly saner,--with all that, it can be readily understood that the district in days gone by was by no means the absolutely quiet place that it is on the day called to-day. 


\section{Changes in Church and School.}

My father has witnessed the two greatest ecclesiastical and educational events of a century - the Disruption and the Education Act. $\mathrm{He}$ has seen four parish ministers, two parochial dominies, and then three schoolmasters, succeeded, owing to the small attendance, by a schoolmistress.

Church and school are now two distinct institutions, the church authorities, as such, not being allowed to have anything to do with the school. In my father's school-days it was different. The master was appointed by the Presbytery, and he was expected to act as precentor in the church, as an elder, and so on. "The minister's day" was the inspection day. The Act changed all that.

Gaelic was one of the subjects regularly tanght, as it was also preached in church. The old parochials, local and Gaelic-speaking men, were, at or after the Act, superseded by English-speaking teachers, and Gaelic at first was not included in the Code. Hence, it has been asserted, its disappearance from school. That is true, in a way; but two points must be remembered. Firstly, in recent years educationists, influenced perhaps by the Celtic Revival, have gone in for "protection" of the old tongue, with what result remains to be seen. Secondly, Gaelic ceased to be preached in church quite as soon as it was given up in school, and over the preaching of the kirk, it need hardly be added, the educational authorities have no control whatever. One fact in regard to the language is that, if it has been losing ground here, it has been establishing itself elsewhere. Dr. James Robertson, referred to at the beginning of these notes, when here on a visit the year before his death, told us in a lecture that he was personally acquainted with places in Canada where nothing but Gaelic is spoken.

In the school curriculum history and geography received little attention, but arithmetic had more. A very few select scholars were taught elementary mathematics and Latin and Greek, but no science whatever.

The session was without a break. There were no holidays at Christmas, and Easter was a word unknown. The three months' summer vacation gave the boys an opportunity to help a little on the farms. The rule for closing was that as soon as a boy saw the first stook he was to go and tell the master. School dropped that very day. The modern educational authorities, the Boards, take no notice whatever of such matters.

The old school-room was in keeping with the times, damp and smoky and practically without a floor, badly lighted (with small windows), and heated by the peats brought by the scholars. There was no prophecy of a soup-kitchen. For dinner the scholar brought a dry "piece," usually half a barley bannock with a slice of cheese. Often most of it was stealthily eaten in school before dinner-time; this giving more leisure at the hour for playing and fighting.

Many old customs prevailed. On Handsel Monday every one had to give the master 6d. But the great affair of the school year, greater 
even than the "minister's day," was cock-fighting day, when every boy paid the master 3d., and was expected to take a cock with him for the "war of the cocks" (as it was called in Gaelic). The whole district was ransacked by schoolboys for a special fighting breed, the gamecocks. Before my father left school, a stop was put to this. No one lamented the passing away of the great day more than the master. He lost many threepences over it.

The coming of the visitors-the fact that the Highlands are the (or at least a) playground of Britain-is a matter of great importance to us, in a way the most important, as the wealthiest class of them, the shooting gentry, are surely and not slowly buying up the bens and glens, and by all the present indications they bid fair to become possessors of more in future.

It may be noticed in a sentence-for the purpose of these jottingsthat, notwithstanding Sir Walter Scott and Rob Roy and the Lady of the Lake, and so on, my father remembers when neither summer lodgers nor shooting tenants came this way, and when the present big hotels were mostly represented by old small inns, of the size of an ordinary farmhouse. It was not till the coming of the Highland Railway that this part of the country was fairly opened up. Circumstances now compel us to think that possibly, nay probably, from such people may come our future landed proprietors and superiors. That opens up the whole question of the relations of landlord and tenant and all it implies. An era of transition is less or more an era of trial and anxiety. What the future has in store for us who knows? We live in hope. As our ancestors weathered the storm in days gone by, so we, as best we may, must do the same in the days that are yet to be.

\section{ELDORADO.}

THE "Empire of Guiana," which may be roughly described as the territory situated in the north of South America between the Orinoco and the Amazon, is probably one of the most unhealthy localities in the world, at least for Europeans. It emerges into the light of history about the year 1531, when Don Diego de Ordas, one of the Conquistadores companions of Cortes, led an expedition of the approved Spanish type against it. His objects were to obtain gold and to increase the area and resources of the already colossal empire of Spain. He was followed by several other Spanish adventurers, of whom Juan Gonsales and Antonio Sedenno were the most successful. Of the latter it is recorded that "he passed by Maracapana in the yeare 1536 to discover El Dorado with 500 chosen men. In his journey he got much gold, and tooke many Indian prisoners, whom he manacled in yrons; and many of them dyed as they were led in the way. The Tigers were fleshed on those dead carkeisses." Apparently cruelty and rapacity were the distinctive marks of all Spanish expeditions in the newly discovered continent, and they thus brought on themselves the bitter hatred of the native tribes and peoples wherever they went, and 